\title{
Invited review: Environmental impacts of dairy processing and products: A review
}

\author{
F. X. Milani, ${ }^{\star 1}$ D. Nutter, $†$ and G. Thomał \\ *Department of Food Science, University of Wisconsin, Madison 53706 \\ †Department of Mechanical Engineering, and \\ ‡Department of Chemical Engineering, University of Arkansas, Fayetteville 72701
}

\section{ABSTRACT}

The objective of this review is to summarize research efforts and case studies to date of the environmental impacts from dairy processing. The pervasiveness of greenhouse gas emission, water use, consumer waste, and other environmental impacts of dairy are described. An outline of the method of choice, the life cycle assessment, for conducting research and deciding appropriate allocation of the impacts is provided. Specific research examples in dairy processing highlight how the representative final product is associated with environmental impacts to air, water, and land. The primary conclusion from the study was the usefulness of life cycle assessment methodology and the need for further research due to limited studies, variable data, and the magnitude of environmental impact.

Key words: dairy processing, greenhouse gas emissions, water use

\section{INTRODUCTION}

Human activity on earth produces more greenhouse gases (GHG), with the associated climate-changing potential, than can be absorbed by natural carbon and nitrogen cycles. About $21 \%$ of all GHG from human activity is estimated to be from the growing, processing, transportation, consumption, and disposal of food (Solomon, 2007). Thus, the examination of food systems is warranted to understand where in the food chain GHG are produced and aid in decisions for their reduction. In a recent report from the United Nations Food and Agriculture Organization (FAO) division of Animal Production and Health titled "Greenhouse gas emissions from the dairy sector" (Gerber et al., 2010), it concludes that the world dairy sector contributes $2.7 \%$, with estimated $\pm 26 \%$ certainty, of the total world anthropogenic GHG. If meat is considered as a coproduct

Received October 22, 2010.

Accepted May 6, 2011

${ }^{1}$ Corresponding author: milani@wisc.edu of the dairy sector, then the contribution to total world anthropogenic GHG is $4.0 \%$. These figures are significant when taken in context that dairy is a single food category. The largest world GHG-contributing sectors are electricity-heat generation, land-use change, transportation, and agriculture, with contributions to GHG of $24.6,18.2,13.5$, and $13.5 \%$, respectively (World Resources Institute, 2010). A direct comparison of world dairy GHG to the world GHG sectors is not totally correct, as world dairy GHG contribution also contributes to the world GHG sectors. A comparison of GHG associated with a dairy food as compared with a food with similar nutritional composition of protein and fat would also illustrate the magnitude of the impact. The associated GHG of cheese is $5.9 \mathrm{~kg}$ of $\mathrm{CO}_{2}-\mathrm{Eq} / \mathrm{kg}$ versus the associated GHG of peanut butter of $0.17 \mathrm{~kg}$ of $\mathrm{CO}_{2}-$ $\mathrm{Eq} / \mathrm{kg}$ (Kramer et al., 1999). The associated GHG in this comparison is 35 times greater for cheese compared with peanut butter.

From the FAO report and other milk studies addressing GHG, emissions prior to milk production up to the farm gate generate the majority of GHG. A large portion of GHG from milk production is associated with cow rumen activity. Decreasing GHG emissions from cows will present a significant challenge in mitigation of methane, as an issue of cost-effectiveness and implementation exists (del Prado et al., 2010). Although dairy processing contributes significantly less to the overall GHG from the life cycle of milk, process improvements may be implemented using existing technology. Decreasing the GHG impact of dairy processing is, therefore, more a matter of economics rather than technological feasibility. Recent and comprehensive energy studies were conducted for fluid milk processing (Xu and Flapper, 2009) and for cheese making (Xu et al., 2009). Both studies indicated large variations in energy use per kilogram of finished product and, thus, meaningful reductions could be achieved with corresponding GHG reductions. Significant interest exists in the environmental impact on air and water associated with dairy. To that end, this review paper presents a brief overview of the life cycle assessment approach commonly used to quantify 
the impact and a discussion of the current literature on decreasing the environmental impact, with primary focus on post-farm dairy processing.

\section{Life Cycle Assessment}

The life cycle assessment (LCA) procedure has gained prominence over the past decade as the method of choice when measuring GHG and other environmental impacts of a product, process, or service. The International Organization for Standardization (ISO) has outlined the principles and framework found in ISO 14040 (ISO, 2006a) and requirements and guidelines found in ISO 14044 (ISO, 2006b). As outlined with the ISO 14040 standard, there are 4 phases of an LCA: goal and scope definition, inventory analysis, impact assessment, and interpretation. A historical accounting of the emergence of the LCA methodology is given by Ekvall (2002). Roy et al. (2009) gave a brief review on dairy and meat as part of an overall food LCA review.

The LCA methodology provides a consistent standard for accounting of the inputs and outputs associated with a product throughout its life cycle. Table 1 provides an example of cradle-to-grave life cycle fluid milk material flow and the relationship of major inputs and outputs that affect the environment.

The input and output flows are accounted for during the inventory analysis phase. Material flow is managed within the unit process, defined as the system studied on the farm or in the plant. The farm or plant system may then be further subdivided into a series of unit processes if more resolution is desired. Major inputs that need to be quantified would include raw milk, water, electricity, fuel, cleaning chemicals, and packaging. Major outputs would be packaged milk products, wastewater, $\mathrm{CO}_{2}$ with other upstream pollutants associated with fossil fuel used in electrical power generation, additional $\mathrm{CO}_{2}$ from natural gas used to make steam, and the associated releases from producing cleaning chemicals and packaging materials. If coproducts exist, then allocation of inputs and outputs may be made to those coproducts. A complete LCA considers a cradleto-grave approach, being an accounting of the raw material extraction and manufacture through the endof-life such as disposal. Truncated LCA-type exercises also may look at selected processes of an entire life cycle. Terms like cradle-to-gate, gate-to-gate, and gateto-grave are typically used. An example of a gate-togate LCA would be a simplified analysis of a fluid milk plant, starting at the point where raw milk enters the plant and ending where packaged milk leaves the plant. The functional unit is the product from the process to which environmental impacts associated with inputs and on-site emissions can be assigned. Functional units 
are typically those that a layperson can understand. For the fluid milk plant example, the functional unit could be a selected package size of milk. Functional units may also be parameters understood by the industry, as with the fluid milk example using kilograms of milk produced in $1 \mathrm{yr}$.

It becomes clear from this simple example that there are additional external products and processes to consider when examining a product life cycle. If products and processes used contribute significantly to the environmental impact of the milk product, then they must be included in the accounting of inputs and outputs for the milk example. Inclusion of all of the conceivable supply chain input and output contributions may compound the complexity of the LCA unless criteria are established to decide if input materials affect the conclusions. The ISO 14044 standard outlines that cut-off criteria shall be clearly described and that an assessment conducted that details the effects of excluding inputs be given in the final report. It is important to note that the initial identification may omit important smaller, but numerous, inputs of mass or energy such that the cumulative contribution from those inputs would be significant. An example that is commonly used is the $1 \%$ rule (EPA, 2006). It states that if a product or process contributes less than $1 \%$ to the input and output of the unit process being studied, then it can be excluded from accounting. In the LCA conducted by Berlin (2002), estimates of the environmental impact from each product or process used in cheese manufacture are provided. An example is total contributions to global warming, given as $8,794 \mathrm{~g}$ of $\mathrm{CO} 2-\mathrm{Eq} / \mathrm{kg}$ of Ängsgården cheese. Examining the individual contributors, the highest impact was from milk production $(94.4 \%)$, the next highest impact was the dairy plant contribution $(4.2 \%)$, whereas the remainder of the contribution was made up of all of the other components and processes (1.4\%). It is interesting to note that other than milk production and the dairy plant contribution, none of the other components used contributed more than $1 \%$ to the process input or output. Although the author makes reference to exclusion of rarely used cleaning chemicals, citing the $1 \%$ rule, they elected to list the components for cheese making even though each one contributed less than 1\%. It would be judicious to understand that a product or process input to the unit process may be smaller than $1 \%$ (e.g., as measured by its mass), but may have a large resource demand, such as energy used in its production, and therefore, would have to be accounted for in the LCA. In addition, cumulative impacts of unaccounted flows should not exceed $5 \%$.

System expansion is used when impacts outside the system under study are significant (Ekvall and Finnve- den, 2001; Ekvall and Weidema, 2004). The issue with system expansion, although providing a more accurate assessment, is that the LCA becomes more complicated when defining which external system is the best substitute for 1 of the coproducts. In trying to understand the system to a level of detail required to make an informed decision about its impact, system expansion may then place more demands on the analysis in terms of cost, timing, and information availability. The principles of allocation are defined within the ISO14044 (ISO, 2006b) standard and a hierarchy for allocation decisions is provided.

\section{Milk Production and Allocation Considerations}

Before milk is received into the processing facility, it is burdened with environmental impacts. Use of LCA for evaluation of the impacts of production of milk and, in particular, cumulative GHG emissions up to the farm gate are numerous. Table 2 provides a summary comparison of GHG reported from selected studies. Differences in the GHG reported can be attributed mainly to the method of growing feed, dairy production methods, manure handling, and allocation method.

An example of allocation by system expansion is seen with the allocation of the cull or end-of-life meat products produced along with milk in Sweden (Cederberg and Stadig, 2003). The general rule is that if both products have economic value, then each should bear part of the production burden. The authors reported that milk output per cow increased over the recent decade and a corresponding decrease occurred in the number of dairy cows. This would seem to be an advantageous gain relative to environmental impact for the dairy industry, but an increase in the number of beef head occurred to compensate for the beef demand. Only a slight increase was found with climate change potential measurement when more beef cattle were raised as compared with dairy cattle.

Relative to the milk and beef allocation decision, Thomassen et al. (2008a) presented a case for not using attributional LCA but instead made a case for consequential LCA. If allocation is to be used for the impact assessment phase, then a sensitivity analysis must be applied to test for the influence of inherent uncertainties on the calculated impact. When a system has multiple products, then the input and output burdens should be allocated appropriately between the multiple products. The attributional LCA is used to describe resource flows within a system of a specified amount relative to the products. Changes to the system that are evaluated using attributional LCA are essentially applied without considering the effect on other processes outside the system boundaries or the effect of external 
Table 2. Summary of life cycle assessment (LCA) studies reporting greenhouse gases (GHG) at the farm gate

\begin{tabular}{|c|c|c|c|c|c|}
\hline Study & $\mathrm{CO}_{2}$-Eq $(\mathrm{kg})$ & $\begin{array}{l}\text { Per functional } \\
\text { unit }\end{array}$ & $\begin{array}{l}\text { Allocation } \\
\text { to milk }(\%)\end{array}$ & $\begin{array}{c}\text { Characterization } \\
\text { factors } \\
\left(\mathrm{CO}_{2}, \mathrm{CH}_{4}, \mathrm{~N}_{2} \mathrm{O}\right)\end{array}$ & $\begin{array}{l}\text { Study } \\
\text { description }\end{array}$ \\
\hline Basset-Mens et al. (2009) & 0.72 & $\mathrm{~kg}$ of milk at farm gate & 85 & $1,21,310$ & New Zealand, estimated national average \\
\hline Casey and Holden (2005) & 1.25 & $\mathrm{~kg}$ of milk at farm gate & - & $1,21,310$ & Ireland average \\
\hline Capper et al. (2009) & 1.35 & $\mathrm{~kg}$ of milk at farm gate & - & 1,2, & US average. 1944 vs. 2007 \\
\hline Cederberg and Flysjö (2004) & 0.9 to 1.04 & $\mathrm{~kg}$ of milk at farm gate & 90 & $1,21,310$ & Sweden, 23 farms \\
\hline Cederberg and Mattsson (2000) & 0.90 to 1.1 & $\mathrm{~kg}$ of ECM at farm gate & 85 & $1,23,296$ & Sweden, organic vs. conventional \\
\hline Cederberg et al. (2009) & 1.02 & $\mathrm{~kg}$ of ECM at farm gate & 85 & $1,25,298$ & Sweden, 1990 vs. 2005 \\
\hline Cederberg et al. (2009) & 1.08 & $\mathrm{~kg}$ of ECM at retail & 85 & $1,25,298$ & Sweden, 1990 vs. 2005 \\
\hline Foster et al. (2007) & 1.14 & $\mathrm{~kg}$ of FCM at farm gate & 100 & $1,21,310$ & UK average \\
\hline Eide $(2002)$ & $\sim 0.54$ to 0.65 & $\mathrm{~kg}$ of milk at end-of-life & 65 & $1,2,0$ & Norway, study of 3 dairies \\
\hline Eide $(2002)$ & $\sim 0.41$ to 0.46 & $\mathrm{~kg}$ of milk at farm gate & 65 & - & Norway, study of 3 dairies \\
\hline Gerber et al. (2010) & 2.4 & $\mathrm{~kg}$ of $\mathrm{FPCM}^{1}$ at retail & $\sim 90$ & $1,25,298$ & International average \\
\hline Gerber et al. (2010) & 1.3 & $\mathrm{~kg}$ of FPCM at retail & $\sim 90$ & $1,25,298$ & US average \\
\hline Gerber et al. (2010) & 1 & $\mathrm{~kg}$ of FPCM at farm gate & $\sim 90$ & $1,25,298$ & US average \\
\hline Guignard et al. (2009) & 1 & $\mathrm{~kg}$ of milk at farm gate & Economic & $1,25,298$ & $\begin{array}{l}\text { Literature review of } 60 \text { studies, } \\
\text { primarily European }\end{array}$ \\
\hline Guignard et al. (2009) & 1.2 & $\mathrm{~kg}$ of milk at end-of-life & Economic & $1,25,298$ & $\begin{array}{l}\text { Literature review of } 60 \text { studies, } \\
\text { primarily European }\end{array}$ \\
\hline Haas et al. (2001) & 1.0 to 1.3 & $\mathrm{~kg}$ of milk at farm gate & - & - & $\begin{array}{l}\text { Southern Germany, intensive, extensive } \\
\text { and organic }\end{array}$ \\
\hline Howden and Reyenga (1999) & 1.04 & $\mathrm{~kg}$ of milk at farm gate & - & $1,21,310$ & Queensland, Australia average \\
\hline Thoma et al. (2010) & 1.2 & $\mathrm{~kg}$ of FPCM at farm gate & 89 (causal), 94.5 (economic) & $1,25,298$ & US average \\
\hline Thomassen et al. ( 2008b) & 1.4 to 1.5 & $\mathrm{~kg}$ of FPCM at farm gate & $90-91$ & $1,21,310$ & Netherlands, organic vs. conventional \\
\hline Vergé et al. (2007) & 1.0 & $\mathrm{~kg}$ of milk at farm gate & - & $1,21,310$ & Canada average \\
\hline
\end{tabular}

${ }^{1} \mathrm{FPCM}=$ fat- and protein-corrected milk. 
processes influencing the system LCA being studied; an often cited example of an unanticipated external consequence is loss of rainforest in Brazil associated with increased corn ethanol production in the United States. For the LCA using an attributional model approach, it is optional to use system expansion to handle coproducts in the allocation. In LCA analysis using a consequential modeling approach, system expansion is needed, as it accounts for the results of production of substitute materials (and the environmental impacts associated with those external changes) when change occurs in the output from the system under study. An example of consequential analysis can be seen with milk output per dairy cow as described earlier by the Cederberg and Stadig (2003) study. If the output of milk per cow increased, then fewer milk cows would be needed, requiring more beef cattle to meet demand. To further explain how consequential analysis may be needed, Schmidt and Weidema (2008) gave an example of the influence of world supplies of vegetable oils. Because different sources of food oils can be used in the same application, substitution of oil types is common and under the influence of market prices. An example was the shift to using more palm oil as the price of palm relative to rapeseed oil decreased; because the environmental impacts of palm and rapeseed oil are not the same, the true impact of the decision to switch to one oil cannot be evaluated without understanding how shifting production to a substitute oil affects the combined system environmental impact. The authors state that many LCA using vegetable oils may need to be recalculated if they did not consider multiple oil markets.

\section{Manufacturing, Packaging, and Consumption}

Thermal Processing. The vast majority of milk is thermally processed at least once during its manufacture to a consumable product. Energy input, therefore, is significant as are the increased resources needed to clean the easily fouled heat exchangers and the remaining plant processing equipment. Improvements in cleaning heat exchangers would provide significant energy and environmental impact reductions (Christian and Fryer, 2006). A review on cleaning heat exchangers is given by Jun and Puri (2005) and concludes that fouling-related cleaning increases the capital need of the process installation, energy demand, water demand, labor cost, and loss in productive processing time. Estimates of category contributions to total cleaning cost of water, cleaning agents, labor, and energy are 25.6, $23.2,23.9$, and $27.3 \%$, respectively (Sandu and Singh, 1991). The total cleaning cost for dairy was calculated to be about $0.5 \%$ of total plant product value. The authors stated that, unlike the large resource demands of cleaning, heat exchanger efficiency and pumping demands are very minimally affected by fouling during the processing of milk.

Stefanis et al. (1997) used LCA as an approach to the evaluation of dairy manufacturing. They presented extensive mathematical modeling of batch processing relative to impacts of air pollution, water pollution, solid wastes, global warming, ozone depletion, photochemical oxidation, and operational cost. An example of water waste parameters with actual data from the plant was also given. The authors noted that, although plant design was important for favorable environmental impacts as influenced by the amount of waste treatment, optimal process designs upstream also had a strong impact. Cleaning also had a significant impact on energy use and waste generation. Using more chemicals in the cleaning process increased the global waste production, but made for a less costly process less time was required to clean. This illustrates the interpretation phase of LCA where evaluation may be subject to external influences as part of the decision-making process. For plants with multiple processes, it was found that parallel cleaning was more efficient and decreased sodium hydroxide use very significantly.

Høgaas Eide and Ohlsson (1998) described large and small dairy processing plants using LCA methodology. They used 2 methods of allocating the environmental loads of energy and water use; a simplified method in which all of the resources used were allocated against the total milk production and a detailed method that was able to segregate unit processes such as fresh milk versus fermented milk products. The detailed method was able to show that some products used more resources than other products. This is contrasted against the simple method that grouped all of the products in the same plant. However, the simple method was easy to conduct, whereas the detailed method relied upon deep knowledge of the division of the resources used. They concluded that the choice of method to use was very much dependent on the goal of the LCA and that each method had sources of error. In 2 reports, Italian researchers (Bianconi et al., 1998; Masoni et al., 1998) conducted plant surveys of butter manufacture and consumption using LCA. Their 4 unit processes were input of raw materials, manufacture, distribution, and waste management of the entire process. They reported that the highest percentage of the selected post-farm inventory category resource use and emissions, with the exception of solid waste, was associated with the manufacture of the product and not packaging, distribution, or end use. The production of polyethylene 
or aluminum for use in packaging was responsible for the highest solid waste in the raw material production stage.

Conversion. Combining milk production, processing, and consumption, Eide (2002) reported on multiple environmental indicators that the agriculture production was significantly larger than other impacts along the chain for a packaged fluid milk product. The total GHG contribution of the entire milk food chain was about $0.65 \mathrm{~kg}$ of $\mathrm{CO}_{2}-\mathrm{Eq} / \mathrm{kg}$ of milk. The average contribution of post-farm gate through consumer disposal was about $0.24 \mathrm{~kg}$ of $\mathrm{CO}_{2}-\mathrm{Eq} / \mathrm{kg}$ of milk. The greatest variation of GHG impact within the steps of the LCA was seen with the dairy processing. About 4 times more GHG impact was associated with small plants as compared with large plants, of which the majority could be assigned to electricity use. Ninety-three percent of the eutrophication potential, as contributions from nitrogen and phosphorous leaching as well as ammonia losses from manure, was linked to farming and on-farm milk losses. The author reported that most of the acidification potential was also associated with agriculture. Most of the ozone depletion potential was split between agriculture and manufacturing, with little contribution by distribution and retail. The study also highlighted major environmental contributors within each unit process. The study by Sonesson and Berlin (2003) reported about $0.14 \mathrm{~kg}$ of $\mathrm{CO}_{2}-\mathrm{Eq} / \mathrm{kg}$ of milk (converted from their reported functional units of metric tonnes per year) with a study starting at the farm gate and continuing through to consumption. Another study by Hospido et al. (2003) reported an LCA for Galician (Spain) milk production and processing. The total GHG contribution was $1.05 \mathrm{~kg}$ of $\mathrm{CO}_{2}-\mathrm{Eq} / \mathrm{kg}$ of milk, whereas the post-farm gate contribution was 0.21 $\mathrm{kg}$ of $\mathrm{CO}_{2}-\mathrm{Eq} / \mathrm{kg}$. The study of US fluid milk (Thoma et al., 2010) reported post-farm-gate emissions of 0.57 $\mathrm{kg}$ of $\mathrm{CO}_{2}-\mathrm{Eq} / \mathrm{kg}$ of milk consumed (28\% of overall), including raw milk transport, processing, packaging, transportation, retail, consumption, disposal, and milk waste.

Berlin (2002) provides a cradle-to-grave LCA for a semi-hard cheese relative to global resource use and environmental impacts. The production of ECM leaving the farm gate contributed much of the total GHG environmental load of the cheese, reported as $8.3 \mathrm{~kg}$ of $\mathrm{CO}_{2}-\mathrm{Eq} / \mathrm{kg}$ of cheese, whereas the process of cheese making contributed $0.4 \mathrm{~kg}$ of $\mathrm{CO}_{2}-\mathrm{Eq} / \mathrm{kg}$ of cheese. The life cycle stages of the product through distribution, retail, and consumer use contributed $0.05 \mathrm{~kg}$ of $\mathrm{CO}_{2^{-}}$ $\mathrm{Eq} / \mathrm{kg}$ of cheese. The study was also comprehensive in calculating the acidification, eutrophication, ozone depleting potentials, and eco-human toxicity potential. The majority of these impacts were from milk produc- tion. The photochemical ozone creation potential was calculated from rumen methane but excluded nitrogen oxide compounds.

According to Feitz et al. (2007), for analysis of plants with varied processes producing multiple products, it would be appropriate to allocate resources used and waste generated in dairy processing based on milk solids content of the products and their association with unit processes. They tabulated use and production data, based on the selected dairy plants surveyed, using a physicochemical allocation matrix that is the summation of average resources used and waste generated for dairy products. They compared several allocation approaches: a large change in the allocation of environmental burdens occurred when the physicochemical method was applied to whey versus using allocation based on protein, mass, or economic value. The whey allocation percentage for either protein, mass, or economic value, was below $4 \%$ for water, electricity, fuel, alkaline cleaners, acid cleaners, and wastewater, but increased to about $10,15,18,20,20$, and $10 \%$, respectively, when physicochemical allocation was used. This example highlights an allocation based upon energy and resource-intensive processes. A similar trend of increases occurred when using physicochemical allocation with cheese, except a decrease was assigned to electricity and fuel use with the shift of that energy to the more energy-intensive processing of whey.

An example of environmental impact influencing the decision-making process is outlined by Berlin et al. (2007) for a yogurt dairy plant with multiple products that required operational changes between production runs and resultant multiple cleanings. The authors used an algorithm to calculate the lowest environmental impact sequence of production as a function of cleanup rules and other parameters of the yogurt products. In a later report, Berlin and Sonesson (2008) extensively applied LCA in the decision-making process as demonstrated by type of production practice: one based on conventional processing rules and the other on sequencing production to minimize the amount of cleaning waste generated. They reported eutrophication, acidification, GHG, and photochemical ozone creation potential. Their conclusion was fewer clean-ups per pound of finished product resulted in less environmental impact. Although this result was expected, what was novel was to report the magnitude of the importance through processing data.

Mass and energy are inventoried systematically within an LCA. However, economic analysis may present a more ambiguous situation due to the nature of value assignment versus physical flow within the LCA. An example is a study comparing cheese production technologies by Castanheira et al. (2006). They pointed 
out that an alternative cheese-making technology, such as membrane concentration of dairy components to increase cheese yield, might result in more environmental impact even when normalized against yield. As seen with many human economic activities that are associated with environmental impact, the value created could justify the environmental impact. Recalling that an LCA is an assessment, the authors were confident that such assessments would lead to reductions in environmental impact from dairy processing. Guinée et al. (2004) provided an excellent outline using industrial chemical and metal production examples of economic allocation as applied to the general LCA, including strategies, multi-functional flow modeling, and impacts of recycling. They suggested that economic allocation provides, in general, the best applicable and consistent approach to modeling multi-functional processes, especially when waste or recycling product flows are involved.

Cleaning, Sanitation, Water Use, and Wastewater. Cleaning in dairy processing is an area of continual examination, optimization, and innovation of which many studies have been conducted. Wastewater effluent will entrain biological and chemical solids from the cleaning of dairy processing equipment. Changani et al. (1997) give a review of major factors involved in dairy equipment fouling. An understanding of these factors can lead to reducing cleaning resource use and effluent loading. Selection of chelating chemicals, when LCA methodology is applied, can lead to better chemical selection criteria when environmental impacts are known and taken within the context of the resources available (Borén et al., 2009). The primary factors found to be influential in their decision analysis was using agents that had no phosphorous, were biodegradable, and were sourced from renewable raw materials.

Cleaning chemical recovery strategies, with the avoidance of solute wastewater discharges, have been implemented with moderate success throughout the dairy processing industry (Trägardh and Johansson, 1998). The focus and successes are with alkaline cleaner recovery using membrane technology. Avoidance of surfactants, and even more so cationic surfactants, in cleaning solutions is needed due to membrane fouling. Filtration and alkaline cleaner recovery run times before fouling are more than acceptable, as long as cleaning processes have been characterized in their consistent chemical use and known organic loads. In another study conducted with yogurt production (Fernandez et al., 2010), the authors found that single-phase commercial detergent could be recovered at a rate of $80 \%$ using the filtrate from reverse osmosis (RO) membranes. Large particulate filters were used upstream to protect the RO modules. Fouling was mainly from precipitated inorganic salts and OM from the process, as none was attributed to the cleaning agents. Recovery and reuse will result in considerable economic savings as well. A review of regeneration for cleaning and processing solutions was done for dairy, vegetable, meat, and fish processing (Mawson, 1997). For dairy, considerable decreases in environmental impact occur with membrane recovery of caustic cleaning solutions but limitations also exist with cumulative contaminants. Membrane life is the biggest factor for selection and payoff timeframes. Cheese brine recovery is successful when avoiding conditions of calcium phosphate fouling by avoiding process temperatures above $20^{\circ} \mathrm{C}$.

Further research into cleaning methods (e.g., enzyme cleaners), may have merit in decreasing the amount of inorganic cleaning chemicals that are difficult to remove from effluent, and thus have an environmental impact (Grasshoff, 2002). A comprehensive LCA, for which GHG were calculated in dairy cleaning, may be best illustrated by Eide et al. (2003). Their study compared 4 clean-in-place methods typically used in the dairy industry. The one-phase alkaline cleaning method or the enzyme cleaning method had less than $10 \%$ of the total energy use, with the corresponding GHG emissions related to that energy, as compared with conventional dairy cleaning methods. When comparing these 2 methods, a moderate improvement in water use exists with the enzyme-based method compared with the one-phase alkaline method. The authors stated that environmental toxicity, as it relates to water effluent of the 4 methods, was not adequately addressed. Instead, they noted that the information on compounds discharged was available for decision making by the stakeholders, as a variety of external factors influence cleaning method selection. As a comparison in a similar study, Wirtanen et al. (2002) reported that enzyme cleaning also had the lowest environmental impact.

A significant environmental impact is seen with the use of Cl-containing compounds for dairy sanitation. The use of ozone instead of $\mathrm{Cl}$-containing compounds for sanitation would have much less impact. Pascual et al. (2007) give a review of the technology and effectiveness. They present a case that the use of ozone for many food industries would result in being at least equal as a sanitizer to Cl-containing compounds, provide a lower cost sanitizer, and eliminate sanitizer-related $\mathrm{Cl}$ content from wastewater.

Fresh water use by a dairy plant relative to the amount of milk processed is significant. This stems from the need to clean holding tanks after every fill cycle and processing equipment frequently to maintain the quality of the milk-derived products. Technologies for water recovery such as RO membrane technology provide vast improvement with effluent streams (Lipnizki 
et al., 2003). Potable water recovery is very prevalent in dairy plants when evaporative processes or RO membranes, or both, are used in water removal (Baskaran et al., 2003). Implementation of this technology can have great impact in decreasing water intake by the dairy plant, as the water from the milk is recovered and used again. The water-to-milk intake ratio is an indicator of how well a dairy plant uses water, which is a combination of condensate reuse and cleaning best manufacturing practices. Another indicator is the waste volume coefficient, which is the volume of milk processes to the wastewater generated. A waste volume coefficient of $0.93 \pm 0.54$ to 1 was calculated from data reported by a wastewater survey conducted on north central US cheese plants (Danalewich et al., 1998). The waste volume coefficient may be more meaningful with plant-to-plant comparisons if the volume of condensate generated from milk is known. Relatively simple systems using UF membrane treatments for cheese whey, followed by nanofiltration, can result in a large reduction in environmental impact of the effluent and of water demand (Minhalma et al., 2007).

Phosphorous is an important consideration in preventing eutrophication in waterways from dairy plant effluent. The removal of $\mathrm{P}, \mathrm{N}$, and $\mathrm{S}$ is still problematic for anaerobic digestion of dairy waste as reported by Karadima et al. (2009). Their results indicate that cheese plant wastewater treated by anaerobic digestion set up for hydrogen production was deemed very toxic, according to their bioassay criteria. However, the authors did point out that the concentrations selected were almost at discharge strength from the digester; so, further assessment of the dilution in waterways and actual environmental impact needs to be conducted. The removal of $\mathrm{P}$ with anaerobic digestion will not occur and, therefore, other technologies are needed to decrease $\mathrm{P}$ concentrations to typical discharge limits. Significant biological P removal can be achieved when combined with anaerobic wastewater treatment, provided a program of dairy solids waste minimization is also used with processing (Bickers et al., 2003).

Packaging, Consumer Behavior, and Disposal. An early LCA accounting of packaging contribution to GHG via energy use is given by Klöpffer and Rippen (1992). They reported on other studies of energy use in producing a package and concluded that returnable glass packaging used 3 times less energy, provided that 20 return trips were made, compared with one-time use dairy product packaging made of paperboard and plastic composites. Landfill disposal would be very favorable for returnable glass end-of-life disposal, as the glass will not decompose as compared with paperboard and plastic; however, incineration of the paperboard component would provide heat energy and be a renew- able GHG carbon-neutral sourced material. Another study (Bloemhof-Ruwaard et al., 2001) compared the costs and environmental impacts of fluid milk packaging with gable-topped cardboard disposable packages or polycarbonate returnable bottles. It was estimated that the returnable bottles made 27 trips. They conducted an LCA and found the disposable gable-topped packaging, when compared with returnable bottles, produced 3.2 times more GHG, 4.5 times more acidification, 1.7 times more smog, 1.4 times more water associated nutrients, and 2 times more human toxicity.

Packaging may still only contribute a small portion of GHG emissions for an entire life cycle for a finished dairy item; however, persistent public concern exists that consumer-derived packaging waste contributes significantly to landfill space and landfill methane emissions. Hanssen (1998) used LCA to examine several packaged consumer goods in Sweden. When evaluated alone, the shelf-stable milk in aseptic packaging contributes about $55 \%$ of the total fossil fuel use for the total life cycle of the milk package. However, the author stated that the contribution to global climate changing potential GHG equivalents were small compared with the large contributions from production and processing. An alternative such as incineration, with its associated toxin release, is also a public concern even when contrasted with the cardboard being a renewable material and, therefore, $\mathrm{CO}_{2}$-emission neutral. Another study conducted in Brazil (Mourad et al., 2008a) examined the environmental impacts of almost the same aseptic milk-type package by comparing the recycling rate of the package alone from 2 to $20 \%$. The scope of the study included significant impacts associated with the manufacture of the packaging roll stock predominantly made from layered cardboard, aluminum, and polyethylene. Also within scope was the environmental impact of the equipment operation used to form and fill the package. Distribution and post-consumer disposal of the package was included; however, consumer behavior from obtaining and using the product was omitted, as well as any upstream contribution of milk production and processing. It was reported that the $20 \%$ recycling rate resulted in a $6 \%$ decrease in energy use and a $9.7 \%$ decrease in energy-derived GHG emissions by a $9 \%$ decrease in biochemical oxygen demand, $10 \%$ decrease in chemical oxygen demand, $6 \%$ decrease in total suspended solids, $11 \%$ decrease in wood for fiber production, $7 \%$ decrease in water use, and $7 \%$ decrease in landfill volume. They reported that recycling cardboard increased total dissolved solids by $57 \%$, but stated this could be overcome with infrastructural change, as demonstrated by other countries with stricter discharge limits. This same group of researchers issued another report (Mourad et al., 2008b), focusing on energy use and GHG, for 
recycling rates of the aseptic package. They reported that increasing the recycling rate from 0 to $70 \%$ would decrease energy use by 24.9 or $37.2 \%$, as a function of only recycling the cardboard or recycling the polyethylene, aluminum, and cardboard, respectively. They also reported that increasing the recycling rate from 0 to $70 \%$ would decrease GHG emissions by $48 \%$ when only recycling the cardboard or by $52 \%$ when recycling the polyethylene, aluminum, and cardboard.

Beyond dairy processing environmental impacts, consumer behavior and packaging design can contribute to food waste. Berlin et al. (2008) outlined the many actors along the yogurt food chain and suggest a Pareto-style approach to improvement. They suggest that consumer behavior may now be a significant problem to address, but also noting that yogurt products inherently have more waste as compared with other consumer dairy products, such as milk and cheese. A recent LCA for common cheese packaging was given by Banar and Cokaygil (2009). The extraction of resources and the use of fossil fuels produced environmental impacts; however, decomposition of the package in the landfill had the greatest impact in producing GHG.

Contrary to popular belief, food miles are not a major contributor to environmental impacts. Weber and Matthews (2008) outlined several food chains throughout their life history and reported the environmental impact. Their analysis and discussion concluded that environmental impact of the miles food travels is small. If consumers wanted to lower their impact on GHG, it would be easier to make a slight modification to the types of food they consume. They estimated the food production-based climate impact for the average US household to be around $8.1 \mathrm{t}$ of $\mathrm{CO}_{2}-\mathrm{Eq} / \mathrm{yr}$ and the delivery of that same food to be about $0.4 \mathrm{t}$ of $\mathrm{CO}_{2}-\mathrm{Eq} /$ yr. Interpolating their data, a decrease in consumption of $16.3 \%$ for red meat or $27.6 \%$ for dairy would decrease the climate impact by the same amount as the delivery climate impact of the same foods. They then state that modest decreases in diet choices could result in effectively having all of the foods being shipped locally.

\section{DISCUSSION}

Dairy processing is the next most significant GHG environmental impact source in the dairy product life cycle, second only to farm production. The technology to decrease or eliminate the environmental impact of dairy processing is available and many examples of success exist in energy GHG mitigation and wastewater treatment by alternative technologies. Many of these improvements may have no effect on dairy materials being processed but are instead peripherally involved. Potential exists to gain additional environmental impact improvement through alternative processing. However, realities of dairy processing exist, which hinder implementation of alternative technologies. The high cost of capital improvements are also exacerbated by the low price margin reality of the industry. The uncertainty of prediction of product quality from the complexity of dairy substrate as a food matrix also is a factor when implementing a new technology and, thus, adds to the risk of scaling-up alternative technologies. The majority of dairy products are minimally processed and quality perception and expectation by consumers has been shaped by the products themselves and distribution practices. An example would be pasteurized refrigerated fresh fluid milk versus aseptic shelf-stable milk within the context of each being popular in different parts of the world.

It is well known that combining many small processing facilities into larger operations will result in energy efficiency gain per unit processed. A study by Ramirez et al. (2006) comparing European countries that underwent some consolidation of their dairy processing industries showed a decrease in environmental impacts, reported as energy efficiency indicator. Their analysis showed that lack of consolidation in segments of a dairy industry was linked to specialization and innovation. The best example of this was the French cheese industry. Whereas Dutch, German, and English cheese industries showed some degree of consolidation, the authors questioned why France was lagging when compared with its peer countries, even though all had access to the same technologies, worker skills, and other resources. Retention of the cheese manufacturing sites occurred in France during the same time period. The authors concluded that as much as a $30 \%$ decrease in energy could be realized, with the corresponding decrease in GHG impact. However, France's cheese industry is highly specialized, which may explain the resistance to consolidation. Wojdalski et al. (2008) concluded that smaller plants were disadvantaged from cleaning and energy utilization similar to findings of Edie's study from 2002. However, water use was significantly lower as compared with larger plants, which they attributed to attentive management. They go on to state that positive environmental benefits of smaller plants could be realized by more flexibility in the use of alternative and renewable fuels and may give smaller plants an advantage in adopting those technologies.

Water use, seen as both the consumption and quality of effluent, is also a concern. Conservation and efficiency in water use with industrial processing has been effectively applied when scarcity of supply or imposed effluent limits, or both, drive the economics of investment (Vanrolleghem et al., 1996). Dense populations result in more demand for water as well as the water 
quality of effluent, which may further add to economic factors of water use for the dairy processor. This may place pressure on the justification of a dairy infrastructure within such a trade area and may contribute to unfavorable market returns. Europe is an example of an area that has both dense populations and significant dairy operations, resulting in competition for the available limited resources. For arid parts of the world, researchers have suggested not investing in expensive water technologies. Instead, countries with a water surplus should trade agricultural commodities as if they contained the equivalent water used to produce the commodity (Hoekstra and Hung, 2005). The net effect would be importing an equivalent amount of water into the arid country.

The technological capability for on-site wastewater treatment is extensive and pervasive throughout many industries, with one of the important goals being decreasing biochemical oxygen demand of the discharged water. Unlike aerobic wastewater treatment, anaerobic digestion may be configured to provide methane, which can be used to generate heat or power through combustion. Provided that most of that methane generated was from agricultural carbon, it would be considered a renewable energy source and, thus, could offset GHG contribution of the processing facility or even a portion of the production GHG generation. A review in the use of anaerobic digesters with dairy wastewater systems is given by Demirel et al. (2005).

\section{CONCLUSIONS}

Earlier environmental impact studies for milk processing have varied methodologies that presented a large variation in results. This variation is further confounded in consideration of the wide range of production and processing methods used. Limited comprehensive and detailed studies exist on the impact of industrial dairy processing on the environment. Also, few studies exist on the environmental impacts of cheese and whey production, and that is in light of the fact that a very significant percentage of the total production of milk is used in cheese. Cheese and whey products may produce high levels of GHG from energy use, consume high levels of water, and have significant wastewater challenges.

It is clear that the LCA tool can be applied in a consistent and visible manner and this will aid in comprehensive approaches to future studies and more systematic interpretation leading to science-based decisions. Public disclosure of additional and extensive research on alternative processing would enable the industry to adopt changes faster, as effects upon key product quality factors would be known. It is also conceivable that the lack of detailed processing research studies examin- ing improvement in environmental impact stems from installations being controlled by private entities with an interest in protecting their proprietary competitiveness. In light of that, however, progress now is being made with the emergence of reportable environmental indices that are incentives for the industry to improve. The rate of innovation for dairy processing may well be justified, as the production of milk at the farm level is responsible for the majority of environmental impacts for a cradle-to-grave milk life cycle and will need considerable investment in the science and technology for reduction in environmental impact of that segment.

The future of dairy products as a food source is undoubtedly compelling due to its uniqueness, desirability, economic value, and nutrition. However, dairy products are associated with large amounts of GHG and other environmental impacts when compared with most foods of similar nutritive content. It may be suggested that other sources of nutrients could replace milk-derived nutrients, based on our current knowledge of nutritional equivalency, and thus have significant environmental impact decreases from the lower dairy consumption rate. However, the benefit of milk macronutrient, micronutrient, and health-promoting factors far outweigh the other detrimental associations of milk with human diet and disease (Ebringer et al., 2008). Dairy nutritional benefits may also well justify the commitment to invest in decreasing GHG environmental impacts by $25 \%$. This would be significant to total world anthropogenic GHG by decreasing the dairy industry's contribution from $4 \%$ to a technically feasible $3 \%$.

\section{ACKNOWLEDGMENTS}

The authors thank Dairy Management Inc. (Rosemont, IL), the College of Agriculture and Life Sciences at the University of Wisconsin-Madison, and University of Wisconsin Extension for support during the preparation of this manuscript.

\section{REFERENCES}

Banar, M., and Z. Çokaygil. 2009. A life cycle comparison of alternative cheese packages. Clean-Soil, Air, Water 37:136-141.

Baskaran, K., L. M. Palmowski, and B. M. Watson. 2003. Wastewater reuse and treatment options for the dairy industry. Water Sci. Tech.: Water Supply 3:85-91.

Basset-Mens, C., S. Ledgard, and M. Boyes. 2009. Eco-efficiency of intensification scenarios for milk production in New Zealand. Ecol. Econ. 68:1615-1625.

Berlin, J. 2002. Environmental life cycle assessment (LCA) of Swedish semi-hard cheese. Int. Dairy J. 12:939-953.

Berlin, J., and U. Sonesson. 2008. Minimising environmental impact by sequencing cultured dairy products: Two case studies. J. Clean. Prod. 16:483-498.

Berlin, J., U. Sonesson, and A.-M. Tillman. 2007. A life cycle based method to minimise environmental impact of dairy production through product sequencing. J. Clean. Prod. 15:347-356. 
Berlin, J., U. Sonesson, and A.-M. Tillman. 2008. Product chain actors' potential for greening the product life cycle. J. Ind. Ecol. 12:95-110.

Bianconi, P., S. Marani, P. Masoni, A. Raggi, B. Sara, D. Scartozzi, and M. Tarantini. 1998. Application of life-cycle assessment to the Italian dairy industry: A case-study. Pages 59-62 in Proc. Int. Conf. Life Cycle Assess. Agric., Agro-Ind. Forest., Brussels, Belgium. Sustainable Energy Systems Division, ENEA, Bologna, Italy.

Bickers, P. O., R. Bhamidimarri, J. Shepherd, and J. Russell. 2003. Biological phosphorus removal from a phosphorus-rich dairy processing wastewater. Water Sci. Technol. 48:43-51.

Bloemhof-Ruwaard, J. M., J. A. E. E. Van Nunen, J. Vroom, A. Van der Linden, and A. Kraal. 2001. One and two way packaging in the dairy sector. ERIM Report Series, Reference No. ERS-2001-58LIS. Accessed Mar. 17, 2010. http://ssrn.com/abstract=370916.

Borén, T., K. Ludvig, K. A. Halldén, and J. Seetz. 2009. Eco-efficiency analysis-Applied to different chelating agents. Int. J. Appl. Sci. Personal Care, Detergents, Specialties 135:2-10.

Capper, J. L., R. A. Cady, and D. E. Bauman. 2009. The environmental impact of dairy production: 1944 compared with 2007. J. Anim. Sci. 87:2160-2167.

Casey, J. W., and N. M. Holden. 2005. The relationship between greenhouse gas emission and the intensity of milk production in Ireland. J. Environ. Qual. 34:429-436.

Castanheira, E. G., R. Nabais, C. J. D. Pereira, A. J. D. Ferreira, and M. A. R. Lopes. 2006. Evaluating the environmental performance of different curd cheese production technologies - the ESAC's dairy case study. Pages 1-11 in Proc. The Quest for Sustainability Conference: The Role of Environmental Management Systems and Tools, ESAC, CERNAS, Sector de Tecnologias do Ambiente, Coimbra, Portugal. Accessed Dec. 12, 2009. http://www.esac. pt/emas@school/EMAS@SCHOOL/Publicacoes/Comunicacoes/ quest_coimbra/t6.pdf.

Cederberg, C., and A. Flysjö. 2004. Life Cycle Inventory of 23 Dairy Farms in South-Western Sweden. The Swedish Institute for Food and Biotechnology (SIK), Gothenburg, Sweden.

Cederberg, C., and B. Mattsson. 2000. Life cycle assessment of milk production-A comparison of conventional and organic farming. J. Clean. Prod. 8:49-60

Cederberg, C., U. Sonnesson, M. Henriksson, V. Sund, and J. Davis. 2009. Greenhouse Gas Emissions from Swedish Production of Meat, Milk, and Eggs 1990 and 2005. The Swedish Institute for Food and Biotechnology (SIK), Gothenburg, Sweden.

Cederberg, C., and M. Stadig. 2003. System expansion and allocation in life cycle assessment of milk and beef production. Int. J. Life Cycle Assess. 8:350-356.

Changani, S. D., M. T. Belmar-Beiny, and P. J. Fryer. 1997. Engineering and chemical factors associated with fouling and cleaning in milk processing. Exp. Therm. Fluid Sci. 14:392-406.

Christian, G. K., and P. J. Fryer. 2006. The effect of pulsing cleaning chemicals on the cleaning of whey protein deposits. Trans. IChemE C 84:320-328.

Danalewich, J. R., T. G. Papagiannis, R. L. Belyea, M. E. Tumbleson, and L. Raskin. 1998. Characterization of dairy waste streams, current treatment practices, and potential for biological nutrient removal. Water Res. 32:3555-3568.

del Prado, A., D. Chadwick, L. Cardenas, T. Misselbrook, D. Scholefield, and P. Merino. 2010. Exploring systems responses to mitigation of GHG in UK dairy farms. Agric. Ecosyst. Environ. 136:318-332.

Demirel, B., O. Yenigun, and T. T. Onay. 2005. Anaerobic treatment of dairy wastewaters: A review. Process Biochem. 40:2583-2595.

Ebringer, L., M. Ferencík, and J. Krajcovic. 2008. Beneficial health effects of milk and fermented dairy products - Review. Folia Microbiol. (Praha) 53:378-394.

Eide, M. H. 2002. Life cycle assessment (LCA) of industrial milk production. Int. J. Life Cycle Assess. 2:115-126.

Eide, M. H., J. P. Homleid, and B. Mattsson. 2003. Life cycle assessment (LCA) of cleaning-in-place processes in dairies. Lebensm. Wiss. Technol. 36:303-314.
Ekvall, T. 2002. Cleaner production tools: LCA and beyond. J. Clean. Prod. 10:403-406.

Ekvall, T., and G. Finnveden. 2001. Allocation in ISO 14041-A critical review. J. Clean. Prod. 9:197-208.

Ekvall, T., and B. Weidema. 2004. System boundaries and input data in consequential life cycle inventory analysis. Int. J. Life Cycle Assess. 9:161-171.

EPA. 2006. Life Cycle Assessment: Principles and Practice. Page 30. US Environmental Protection Agency, Cincinnati, $\mathrm{OH}$.

Feitz, A. J., S. Lundie, G. Dennien, M. Morain, and M. Jones. 2007. Generation of an industry-specific physico-chemical allocation matrix. Int. J. Life Cycle Assess. 12:109-117.

Fernandez, P., F. A. Riera, R. Álvarez, and S. Álvarez. 2010. Nanofiltration regeneration of contaminated single-phase detergents used in the dairy industry. J. Food Eng. 97:319-328.

Foster, C., E. Audsley, A. Williams, S. Webster, P. Dewick, and K. Green. 2007. The environmental, social and economic impacts associated with liquid milk consumption in the UK and its production. Project code EVO 2067. Defra, London, UK.

Gerber, P., T. Vellinga, K. Dietze, A. Falcucci, G. Gianni, J. Mounsey, L. Maiorano, C. Opio, D. Sironi, O. Thieme, and V. Weiler. 2010. Greenhouse gas emissions from the dairy sector-A life cycle assessment. Page 95. FAO, FIL/IDF, Brussels, Belgium.

Grasshoff, A. 2002. Enzymatic cleaning of milk pasteurizers. Trans. IChemE C 80:247-252.

Guignard, C., F. Verones, Y. Loerincik, and O. Jolliet. 2009. Environmental/ecological impact of the dairy sector. Bull. Int. Dairy Fed. 436. Int. Dairy Fed., Brussels, Belgium.

Guinée, J. B., R. Heijungs, and G. Huppes. 2004. Economic allocation: Examples and derived decision tree. Int. J. Life Cycle Assess. 9:23-33.

Haas, G., F. Wetterich, and U. Köpke. 2001. Comparing intensive, extensified and organic grassland farming in southern Germany by process life cycle assessment. Agric. Ecosyst. Environ. 83:43-53.

Hanssen, O. J. 1998. Environmental impacts of product systems in a life cycle perspective: a survey of five product types based on life cycle assessments studies. J. Clean. Prod. 6:299-311.

Hoekstra, A. Y., and P. Q. Hung. 2005. Globalisation of water resources: international virtual water flows in relation to crop trade. Glob. Environ. Change 15:45-56.

Høgaas Eide, M., and T. Ohlsson. 1998. A comparison of two different approaches to inventory analysis of dairies. Int. J. Life Cycle Assess. 3:209-215.

Hospido, A., M. T. Moreira, and G. Feijoo. 2003. Simplified life cycle assessment of Galician milk production. Int. Dairy J. 13:783-796.

Howden, S. M., and P. J. Reyenga. 1999. Methane emissions from Australian livestock: Implications of the Kyoto protocol. Aust. J. Agric. Res. 50:1285-1291

ISO. 2006a. ISO 14040: Environmental management-Life cycle assessment-Principles and framework. International Organization for Standardization, Geneva, Switzerland.

ISO. 2006b. ISO 14044: Environmental management-Life cycle assessment, life cycle impact assessment. International Organization for Standardization, Geneva, Switzerland.

Jun, S., and V. M. Puri. 2005. Fouling models for heat exchangers in dairy processing: A review. J. Food Process Eng. 28:1-34.

Karadima, C., C. Theodoropoulos, and J. Iliopoulou-Georgudaki. 2009. Environmental hazard assessment of cheese manufacturing effluent treated for hydrogen production. Bull. Environ. Contam. Toxicol. 83:428-434.

Klöpffer, W., and G. Rippen. 1992. Life cycle analysis and ecological balance: methodical approaches to assessment of environmental aspects of products. Environ. Int. 18:55-61.

Kramer, K. J., H. C. Moll, S. Nonhebel, and H. C. Wilting. 1999. Greenhouse gas emissions related to Dutch food consumption. Energy Policy 27:203-216.

Lipnizki, J., S. Casani, and G. Jonsson. 2003. Optimisation of water savings and membrane processes. Water Sci. Tech.: Water Supply. 3:289-294. 
Masoni, P., B. Sara, D. Scartozzi, M. Tarantini, and A. Raggi. 1998. A life cycle assessment pilot study in an Italian dairy company. Pages 193-196 in Proc. 3rd Int. Conf. EcoBalance, Tsukuba, Japan.

Mawson, A. J. 1997. Regeneration of cleaning and processing solutions using membrane technologies. Trends Food Sci. Technol. 8:7-13.

Minhalma, M., V. Magueijo, D. P. Queiroz, and M. N. Pinho. 2007 Optimization of "Serpa" cheese whey nanofiltration for effluent minimization and by-products recovery. J. Environ. Manage. 82:200-206.

Mourad, A. L., E. E. C. Garcia, G. B. Vilela, and F. von Zuben. 2008a Environmental effects from a recycling rate increase of cardboard of aseptic packaging system for milk using life cycle approach. Int. J. Life Cycle Assess. 13:140-146.

Mourad, A. L., E. E. C. Garcia, G. B. Vilela, and F. Von Zuben. 2008b. Influence of recycling rate increase of aseptic carton for long-life milk on GWP reduction. Resour. Conserv. Recycling 52:678-689.

Pascual, A., I. Llorca, and A. Canut. 2007. Use of ozone in food industries for reducing the environmental impact of cleaning and disinfection activities. Trends Food Sci. Technol. 18:S29-S35.

Ramirez, C. A., M. Patel, and K. Blok. 2006. From fluid milk to milk powder: Energy use and energy efficiency in the European dairy industry. Energy 31:1984-2004.

Roy, P., D. Nei, T. Orikasa, Q. Xu, H. Okadome, N. Nakamura, and T. Shiina. 2009. A review of life cycle assessment (LCA) on some food products. J. Food Eng. 90:1-10.

Sandu, C., and R. K. Singh. 1991. Energy increase in operation and cleaning due to heat-exchanger fouling in milk pasteurization. Food Technol. 45:84-91.

Schmidt, J. H., and B. P. Weidema. 2008. Shift in the marginal supply of vegetable oil. Int. J. Life Cycle Assess. 13:235-239.

Solomon, S. 2007. Climate Change 2007: The Physical Science Basis. Cambridge University Press, New York, NY.

Sonesson, U., and J. Berlin. 2003. Environmental impact of future milk supply chains in Sweden: A scenario study. J. Clean. Prod. $11: 253-266$.

Stefanis, S. K., A. G. Livingston, and E. N. Pistikopoulos. 1997. Environmental impact considerations in the optimal design and scheduling of batch processes. Comput. Chem. Eng. 21:1073-1094.

Thoma, G., J. Popp, D. Shonnard, D. Nutter, R. Ulrich, M. Matlock, D. S. Kim, Z. Neiderman, C. East, F. Adom, N. Kemper, and A.
Mayes. 2010. Greenhouse gas emissions from production in fluid milk in the US. Dairy Management Inc., Rosemont, IL.

Thomassen, M. A., R. Dalgaard, R. Heijungs, and I. de Boer. 2008a. Attributional and consequential LCA of milk production. Int. J. Life Cycle Assess. 13:339-349.

Thomassen, M. A., K. J. van Calker, M. C. J. Smits, G. L. Iepema, and I. J. M. de Boer. 2008b. Life cycle assessment of conventional and organic milk production in the Netherlands. Agric. Syst. 96:95-107.

Trägardh, G., and D. Johansson. 1998. Purification of alkaline cleaning solutions from the dairy industry using membrane separation technology. Desalination 119:21-29.

Vanrolleghem, P. A., U. Jeppsson, J. Carstensen, B. Carlsson, and G. Olsson. 1996. Integration of wastewater treatment plant design and operation - a systematic approach using cost functions. Water Sci. Technol. 34:159-171.

Vergé, X. P. C., J. A. Dyer, R. L. Desjardins, and D. Worth. 2007. Greenhouse gas emissions from the Canadian dairy industry in 2001. Agric. Syst. 94:683-693.

Weber, C. L., and H. S. Matthews. 2008. Food-miles and the relative climate impacts for food choices in the United States. Environ. Sci. Technol. 42:3508-3513.

Wirtanen, G., S. Langsrud, S. Salo, U. Olofson, H. Alnas, M. Neuman, J. P. Homleid, and T. Mattila-Sandholm. 2002. Evaluation of Sanitation Procedures for Use in Dairies. VTT Publications 81. Technical Research Center of Finland, Espoo, Finland.

Wojdalski, J., B. Dróżdż, and H. Brocki. 2008. Effectiveness of electrical energy and water consumption in a small-size dairy processing plant. TEKA Kom. Mot. Energ. Roln. 8:303-309.

World Resources Institute. 2010. World GHG Emissions Flow Chart. Vol. 2010. World Resources Institute, Washington, DC.

$\mathrm{Xu}$, T., and J. Flapper. 2009. Energy use and implications for efficiency strategies in global fluid-milk processing industry. Energy Policy 37:5334-5341.

Xu, T., J. Flapper, and K. J. Kramer. 2009. Characterization of energy use and performance of global cheese processing. Energy $34: 1993-2000$ 